\title{
Archaeal Diversity in a Municipal Wastewater Sludge
}

\author{
Daniel Williams ${ }^{1}$ and James W. Brown ${ }^{2 *}$ \\ ${ }^{1}$ Department of Biology, North Carolina Central University, Durham, NC 27707, USA; ${ }^{2 *}$ Department of Mi- \\ crobiology, North Carolina State University, Raleigh, NC 27695, USA
}

Received: September 21, 2010 / Accepted: November 11, 2010

\begin{abstract}
$T$ he diversity of Archaea in a municipal wastewater sludge sample was investigated by amplification of ribosomal RNA genes from sludge DNA using archaeal-specific primers. Surprisingly, a large fraction (32\%) of these sequences were from Halobacteriales, not previously seen in surveys of wastewater sludge. Other abundant sequences were from members of uncultivated 'environmental' archaeal groups that are commonly detected in sludge and sediment environments. Only a few distant relatives of Methanosarcina (which are commonly thought of as the predominant methanogenic species in sludge environments) were detected.
\end{abstract}

Key Words: Archaea, methanogen, halophile, Euryarchaea, Crenarchaea.

\section{Introduction}

Anaerobic digestion of wastewater sludge involves the conversion of organic carbon compounds into acetate, formate, hydrogen, and $\mathrm{CO}_{2}$ by a consortium of microorganisms (reviewed in Ferry, 1993). Methanogenic Archaea utilize these substrates to produce methane. Classically, the methanogens attributed to this process are Methanosarcina barkeri and relatives, which can use a relatively wide range of substrates for methanogenesis (reviewed in Whitman et al., 1991). Surveys of archaeal populations in wastewater sludges have generally found primarily Methanomicrobia, including both Methanosarcinales and Methanomicrobiales, as well as 'environmental' Euryarchaea and Crenarchaea of unknown phenotypes. As part of an early

* Corresponding author: james_brown@ncsu.edu comparative analysis of ribonuclease P (RNase P) RNA structure in Archaea, we used DNA isolated from digested anaerobicsludge from a municipal wastewater cesspool (euphemistically known as 'lagoon's) as a source of environmental RNase P RNA gene sequences (Harris et al., 2001). We were surprised that no sequences related to those of Methanosarcina were obtained, knowing that the primers used in the polymerase chain reactions were capable of amplifying the RNase P RNA sequence from at least $M$. barkeri. We therefore investigated the phylogenetic diversity of Archaea in this environment by analysis of ribosomal RNA sequences amplified from this DNA using archaeal-specific polymerase chain reaction (PCR) primers.

\section{Materials and Methods}

DNA from a sample of anaerobically-digested sludge from the Cary South Municipal Treatment Plant was isolated previously (Harris et al., 2001). Small subunit ribosomal RNA (ssu-rRNA) genes were amplified from this DNA using primers 8FAPL (GGCTGCAGTCTAGATCCGGTTGATCCTGCCGG) and 1492RPL (GGCTCGAGCGGCCGCCCGGGTTACCTTGTTACGACTT) (Edwards et al., 1989; Stackebrandt \& Liesack, 1993). $P C R$ reactions were performed in buffer containing $50 \mathrm{mM} \mathrm{KCl}$, $10 \mathrm{mM}$ tris(hydroxymethyl)aminomethane hydrochloride (Tris-Cl) (pH 8.3), $1.5 \mathrm{mM}$ each dGTP, dCTP, dATP, and dTTP, 0.05\% Nonident $\mathrm{P} 40,5 \%$ acetamide, and $2 \mathrm{mg} / \mathrm{ml}$ of each primer. Reactions were incubated for an initial $2 \mathrm{~min}$ at $94^{\circ} \mathrm{C}$ and amplified for 30 cycles at $92{ }^{\circ} \mathrm{C}$ for $1.5 \mathrm{~min}, 55^{\circ} \mathrm{C}$ for $1.5 \mathrm{~min}, 72{ }^{\circ} \mathrm{C}$ for $0.5 \mathrm{~min}$ followed by a final extension step at $72{ }^{\circ} \mathrm{C}$ for $7 \mathrm{~min}$. 
Amplification products were digested with Notl and Pstl and separated by agarose gel electrophoresis (3\% NuSieve GTG; FMC, Rockland, ME). Gel slices containing ca. $1.5 \mathrm{kbp}$ products were excised, melted at $65^{\circ} \mathrm{C}$, liquified with AgarACE (Promega, Madison, WI), and used directly in ligation reactions containing Notl and Pstl-digested pBluescript KS+ DNA (Stratagene, now Agilent Tech., Santa Clara, CA). Ligation reactions were used to transform competent $E$. coli strain $\mathrm{DH} 5 \alpha$.

Fifty-two clones containing ca. $1.5 \mathrm{kbp}$ insertions were initially assessed from sequence data obtained from either end of each clone. The 35 non-chimeric (identified using CHECK_CHIMERA \{Maidak et al., 2000\}), full-length archaeal ssu-rRNA clones fell into 13 groups of $\geq 99 \%$ sequence identity. The complete sequence of a single representative from each of these 13 groups was determined (accession numbers AF424763 - AF424775). Each sequence was used to search the National Center for Biotechnology Information (NCBI) database for the most similar sequence (and in cases where this was an uncultivated 'environmental' sequence, the most similar sequence from a named, cultivated specie); these sequences were added to an alignment

\section{Estimated evolutionary distance}

$0 \overline{0.1 \text { substitutions / position }}$

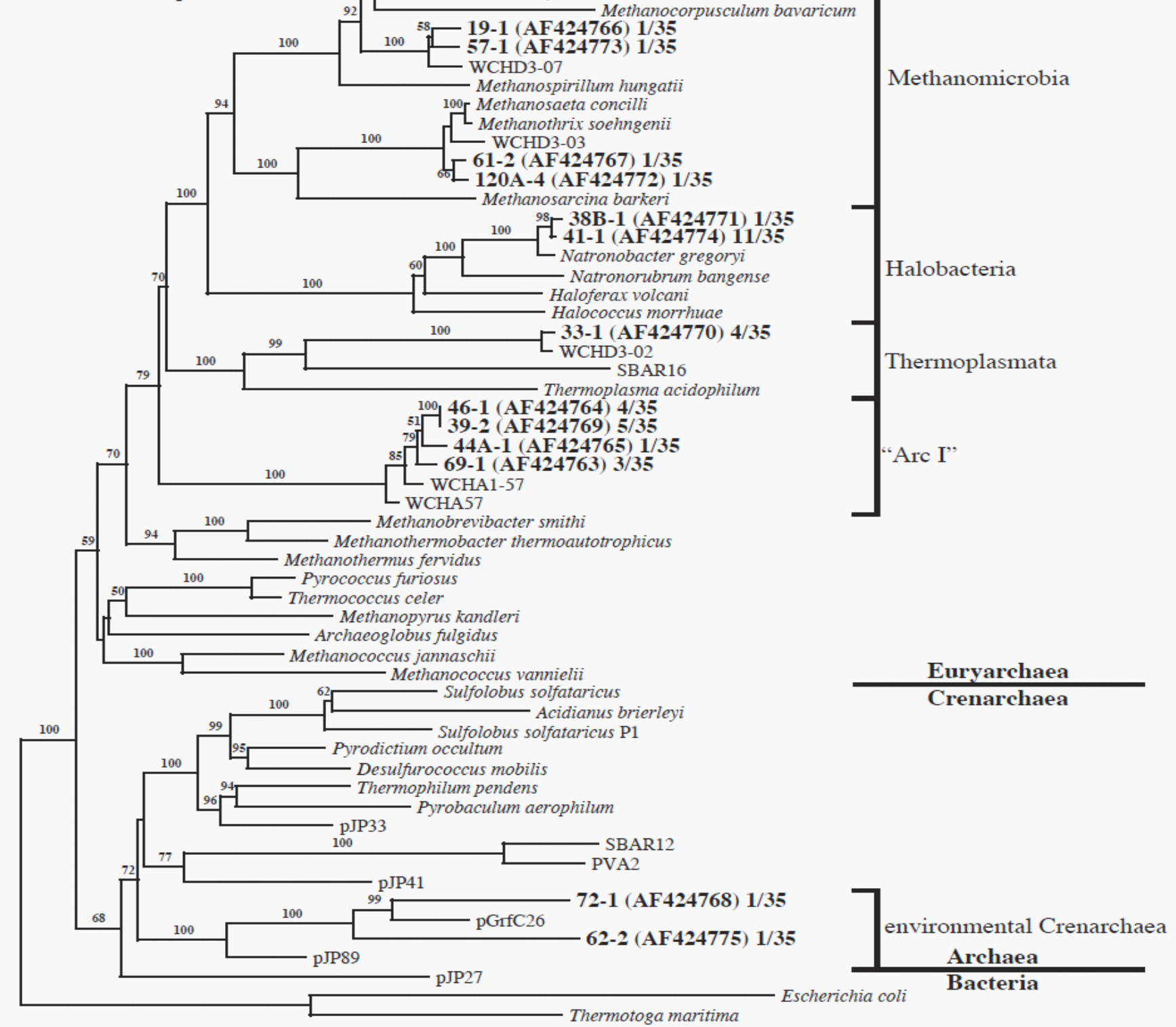

Fig. 1. Phylogenetic analysis of wastewater sludge ssu-rRNA sequences. This tree was constructed by the neighbor-joining method using PHYLIP (Felsenstein, 1989). The alignment contained a representative sampling of sequences from the RDP (Cole et al., 2009) and the sequence most similar to each sludge sequence available in the NCBI/GenBank database (see text). The Escherichia coli and Thermotoga maritima sequences served as outgroup. The percentage of internal branches present in trees from 1000 bootstrap sampling of the alignment are shown above each branch; values below $50 \%$ and those not present in the consensus of the bootstrapped trees are not shown. The sludge sequences fell into the same phylogenetic groups in both parsimony and maximum-likelihood analyses (data not shown). 
of sequences representing the major phylogenetic groups of Archaea extracted from the Ribosomal Database Project (Cole et al., 2009). Phylogenetic analysis of this alignment was performed using PHYLIP (http://evolution.genetics.washington.edu/ phylip.html; Felsenstein, 1989) (See Fig. 1).

\section{Results and Discussion}

The archaeal wastewater sludge ssu-rRNA sequences fell into six phylogenetic clusters, five of which are euryarchaeal, the remainder (containing only 2 sequences) crenarchaeal (see Figure). No bacterial, eukaryotic or organellar sequences were obtained.

The largest group of sequences (46-1, 39-2, 44A-1, and 691,13 sequences representing $38 \%$ of the total) was related to a large group of 'environmental' Euryarchaea known as the 'Arcl' group, from which no cultivated species have been identified, and therefore no specific phenotypic data are available (Chouari et al., 2005). However, Arcl-group sequences are commonly found in surveys of wastewater sludge, sediment, and other methanogenic environments, and the phylogenetic placement of this group suggests that they are methanogenic, most likely utilizing hydrogen and one-carbon compounds (Riviere et al., 2009). Furthermore, members of this group have been shown to grow in the presence of formate or $\mathrm{CO}_{2}$ and hydrogen, although the production of methane specifically by these organisms has not been demonstrated (Chouari et al., 2005).

Surprisingly, the next largest cluster of sequences, comprising $32 \%$ of the total (eleven 41-1 sequences and a single $38 \mathrm{~B}-1$ sequence), was related to alkaliphilic members of the Halobacteriales (which, despite the name are Archaea rather than Bacteria). Sequence 41-1 was the most frequent single sequence to occur in the data set. Halobacteriales have not previously been reported in wastewater sludge. Consistent with the identification of these sequences is the observation that aerobic enrichment cultures in media designed for Halobacteria (American Type Culture Collection media 974 and 1590, and Luria broth with $4 \mathrm{M} \mathrm{NaCl}$ prepared using mineral water) grow quickly when inoculated with small amounts of this wastewater sludge. The presence of these organisms in wastewater sludge implies the presence of alkaline hypersaline microenvironments. In this anaerobic environment, it is expected that these organisms are growing photoheterotrophically, as do the purple non-sulfur Alphaproteobacteria that are well-known inhabitants of wastewater lagoons (see, for example, Do et al., 2003).

Sequence 33-1 (4 sequences, 12\% of the total) is related to another environmental euryarchaeal group, exemplified by sequence SBAR16, from the Santa Barbara channel (Delong, 1992) and distantly related to the genus Thermoplasma. The phenotypes of this group of organisms are unknown, but they presumable are not methanogenic.

No sequences closely related to the genus Methanosarcina were obtained. However, four sequences, in two groups (with each of the four sequences occurring only once in the data set), were members of the Class Methanomicrobia. Clones 61-2 and 120A-4 were members of the Methanosarcinales, but were closely related to the genera Methanothrix and Methanosaeta rather than to Methansarcina. Clones 19-1 and 57-1 were members of the Methanomicrobiales, and most closely related to environmental clone WCHD3-07 and the genera Methanocullex and Methanospirillum. Indeed, the most obvious green autoflourescent (from methanogenic cofactors F420 (DiMarco et al., 1990)) organisms seen in these sludge samples, and in mesophilic methanogen enrichment cultures from these samples grown using either $\mathrm{CO}_{2} / \mathrm{H}_{2}$ or methanol, are morphologically similar to Methanospirillum. These sequences presumably represent the methanogens in the wastewater environment utilizing hydrogenindependent substrates, e.g. methanol and acetate.

Sequences $72-1$ and $52-2$ ( 2 sequences; $6 \%$ of the total) are related to a little-known group of environmental crenarchaeal sequences exemplified by pJP89 from Obsidian Pool, Yellowstone National Park (Barnes et al., 1994), and most closely related to the presumably mesophilic pGrfC26, from a freshwater lake sediment (Hershberger et al., 1996). The phenotypes of these organisms is not known, but environmental Crenarchaea sequences are commonly found in surveys of wastewater environments, soils and sediments, and these organisms have been shown to be physically associated with methanogenic Euryarchaea in sludge environments (Collins et al., 2005). Sequences 72-1 and 52-2 are not related to known ammonia-oxidizing Crenarchaea.

This analysis represents a qualitative view of Archaea a very complex and dynamic environment. Nevertheless, the phylogenetic groups seen in this study, and even their relative proportions, are consistent with those seen in a number of molecular phylogenetic analyses of sludge environments (for example, Riviere et al., 2009) except for the detection of Halobacteria. The relative abundance of the halobacterial sequences obtained could well reflect bias in the PCR reactions, a well-established issue with any PCR-based survey (reviewed in von Wintzingerode, et al., 1997), but the presence of Halobacteria in the original sludge sample, and others taken at the same site over the course of 3 years, was confirmed by their growth in enrichment cultures. What role they play in this ecosystem, and whether their presence is an idiosyncrasy of this site or has been overlooked in other wastewater sites, are not known.

\section{Acknowledgments}

We thank Mary Ellen Woods, Beverly Vucson, Dr. Shermalyn Greene, and Dr. Elizabeth Haas for assistance with this work. This work was supported by the North Carolina Waste Management Program, the North Carolina Agriculture Foundation, and $\mathrm{NIH}$ grant GM52894 to JWB.

\section{References}

Barnes SM, RE Fundyga, MW Jeffries, and NR Pace (1994) Remarkable archaeal diversity detected in a Yellowstone National Park hot spring environment. Proc. Natl. Acad. Sci. USA 91(5):1609-1613.

Chouari R, D Le Paslier, P Daegelen, P Ginestet, J Weissenbach, and A. Sghir (2005) Novel predominant archaeal and bacterial groups revealed by molecular analysis of an anaerobic sludge digester. Environ. Microbiol. 7(8): 1104-1115. 
Cole JR, Q Wang, E Cardenas, J Fish, B Chai, RJ Farris, AS Kulam-SyedMohideen, DM McGarrell, T Marsh, GM Garrity, and JM Tiedje (2009) The Ribosomal Database Project: improved alignments and new tools for rRNA analysis. Nucleic Acids Res. 37(Database issue): D141-D145.

Collins G, L O'Connor, T Mahony, A Gieseke, D de Beer, and V O'Flaherty (2005) Distribution, localization, and phylogeny of abundant populations of Crenarchaeota in anaerobic granular sludge. Applied Environ. Microbiol. 71 (11):7523-7527.

Delong EF (1992) Archaea in coastal marine environments. Proc. Natl. Acad. Sci. USA 89(1 2):5685-5689.

DiMarco AA, TA Bobik, and RS Wolfe (1990) Unusual coenzymes of methanogens. Ann. Rev. Biochemistry 59:355-394.

Do YS, TM Schmidt, JA Zahn, ES Boyd, A Mora, and AA DiSpirito (2003) Role of Rhodobacter sp. strain PS9, a purple non-sulfur photosynthetic bacterium isolated from an anaerobic swine waste lagoon, in odor remediation. Appl. Environ. Microbiol. 69(3):1710-1720.

Edwards U, T Rogall, H Blöcker, M Emde, and EC Böttger (1989) Isolation and direct complete nucleotide determination of entire genes: characterization of a gene coding for 165 ribosomal RNA. Nucleic Acids Res. 17(19):7843-7853.

Felsenstein J (1989) PHYLIP - Phylogeny Inference Package (version 3.2). Cladistics 5:164-166.
Ferry JG (1993) Methanogenesis. Chapman \& Hall.

Harris JK, ES Haas, D Williams, DN Frank, and JW Brown (2001) New insight into RNase P RNA structure from comparative analysis of the archaeal RNA. RNA 7(2):220-232.

Hershberger KL, SM Barnes, AL Reysenbach, SC Dawson, and NR Pace (1996) Wide diversity of Crenarchaea. Nature 384(6608):420

Maidak BL, JR Cole, CT Parker Jr, GM Garrity, N Larsen, B Li, TG Lilburn, MJ McCaughey, GJ Olsen, R Overbeek, S Pramanik, TM Schmidt, JM Tiedje, and CR Woese (2000) The RDP (Ribosomal Database Project) continues. Nucleic Acids Res. 28(1):173-174.

Riviere D, V Desvignes, E Pelletier, S Chaussonnerie, S Guermazi, J Weissenbach, T Li, P Camacho, and A Sghir (2009) Toward the definition of a core of microorganisms involved in anaerobic digestion of sludge. ISME J. 3:700-714.

Stackebrandt E, and W Liesack (1993) Nucleic acids and classification. In: Goodfellow M, AG O'Donnell (ed) Handbook of new bacterial systematics. Academic Press. pp. 152-189.

Von Wintzingerode F, UB Göbel, and E Stackebrandt (1997) Determination of microbial diversity in environmental samples: pitfalls of PCR-based rRNA analysis. FEMS Microbiol. Rev. 21(3):213-229.

Whitman WB, TL Bowen, and DR Boone (1991) The methanogenic bacteria. In: A. Barlows, HG Truper, M Dworkin, W Harder, KH Schleifer (ed) The prokaryotes. Springer-Verlag. pp 717-768. 